\title{
ВЕСЕЛА ПЕСНИЧКА „НАУКА”: КОМПАРАТИВНИ ПРИСТУП ПЕСМАМА У ВЕЗАНОМ СТИХУ БОРИСЛАВА РАДОВИЋА И ИВАНА СЛАМНИГА
}

\begin{abstract}
У раду се компаративно анализирају песме у везаном стиху српског песника Борислава Радовића и хрватског аутора Ивана Сламнига, публиковане током 70-их и 80-их година XX века. У фокусу анализе је употреба иронијских поступака при тематизовању метафизичких мотива и питања песничког стваралаштва, у појединим случајевима уз интертекстуалне везе са барокном дубровачком књижевношћу (Сламниг), или у оквирима рефлексије о природи мита или савремених медија (Радовић). Указује се на специфичност уведене ироније, тј. на остваривање значења као иронизованих и истовремено лишених ироније. На крају, значај сугерисаних поступака се сагледава у епохалном контексту, као пример модернистичког третмана метафизичких и стваралачких питања у време успона постмодерних поетика.

Кључне речи: Борислав Радовић, Иван Сламниг, везани стих, иронија, метафизика, модернизам, полиперспективизам.
\end{abstract}

Борислав Радовић (1935-2018) и Иван Сламниг (1930-2001) су аутори чије су песме, посебно током 70-их и 80-их година прошлог века, биле репрезентативне за многе моделе високомодернистичког песничког изражавања. Дистинкције између ова два важна песника српске, односно хрватске књижевности, наравно, постоје: стваралачки почеци Борислава Радовића су, за разлику од раних радова Ивана Сламнига, повезани са надреалистичким песничким наслеђем; с друге стране, много је оправданије говорити да елементи постмодернистичке поетике постоје у песмама хрватског аутора, поготово у оним публикованим током девете и десете деценије XX века.

И када је реч о песничким текстовима који Радовића и Сламнига смештају у исто, високомодернистичко поетичко поље, јасно је да међу њима постоје приметне разлике. ${ }^{1}$ Ипак, песме у везаном стиху су поље стваралаштва

\footnotetext{
*g.korunovic@gmail.com

1 Зрели песнички израз српског аутора подразумева укрштање низа поступака, са различитим степеном присуства сваког од њих у зависности од песме: најпре, дескриптивне деони-
} 
које приближава Радовића и Сламнига. Компаративним читањем таквих њихових остварења - публикованих током 70-их и 80-их година, дакле, у зрелим етапама стваралаштва - могуће је уочити да оба аутора (често хуморно-иронијски) приступају метафизичким и стваралачким питањима. Шта их додатно зближава, а шта разликује у таквим оквирима песничког израза?²

\section{Лирске студије у тамном и весела осветљења}

Песме Борислава Радовића у везаном стиху неретко подразумевају дескриптивну деоницу формирану на параболичним основама. Саставни чинилац такве песничке конструкције често је модернистички и у основи иронијски поступак - транспоновање тривијалних детаља свакодневице у песнички релевантан и смисаоно прегнантан резултат. Управо на такав начин је устројена песма „Студија у тамном”, ${ }^{3}$ у којој извесни „господин”, сав „нов као космички анатом”, бива усредсређен на мрљу „на дамасту бељем од снега”, која, иако за друге ирелевантна, њега „уводи у мрак првог реда”. То што лирски јунак по њој тражи обрисе „мрља наврлих из подсвести”, не

це које добијају параболичне обрисе; затим, у различитој мери, од текста до текста, присутна елиптичност у изразу, ускраћивање информација о назначеној лирској ситуацији; алузивно-депатетизовани израз уместо повишено експлицитног и исповедног говора; ретко када наглашено, али ипак присутно уткивање интертекстуалне мреже; симболички потенцијал уведених мотива уз митско-архетипску потку певања. С друге стране, Сламниг изразитије посеже за иронично позиционираним лирским Ја, неретко самоироничним, склоним духовитим обртима у исказивању и дискретно демистификаторским односом према различитим облицима идеолошког мишљења, као и према широком спектру стереотипа који могу генерисати живот свакодневице, третирајући спорадично и саму (интер)текстуалност на начин који антиципира постмодерно поимање књижевности.

2 За поље анализе одбране су зреле фазе стваралаштва оба аутора јер се поклапају са временом када је и у српској и у хрватској књижевности интензиван сусрет модернистичких и постмодернистичких/неоавангардних поетика, те се Радовићеве и Сламнигове песме у везаном стиху испостављају као специфичан одраз те динамике. Њихове песме везаног стиха неретко реализују један могући вид модернистичке ироније, условљене управо увођењем риме, спорадично рефлектујући - посебно у случају Сламнигове поетике - епохално симптоматични, текстоцентрични поетички заокрет, с евидентним померањима ка постмодернизму. Осим тога, ране Радовићеве песме у којима се препознаје рима немају много додира са Сламниговом раном поетиком, будући да на почетку стваралачког пута у песмама српског аутора ,рима је везана за озбиљну, емоционално обележену садржину, у којој нема отклона ни од света песме ни од света уопште“" (Јовић 2018: 61), што нема много сродног са Сламниговим почецима у којима је било и егзистенцијалистичких и иронично-субверзивних тонова.

${ }^{3}$ Овде наводимо текст читаве песме: „На крају, кад већ коњак служе / сваком по жељи, ништа мање, / и дамама доносе руже / и капуте пред затварање, // господин, нагнут над открићем / на први поглед сасвим просте / мрље што, изазвана пићем / сличним кафи, на друге госте // не оставља, прилично бледа,/ дубљи утисак, а што њега/ уводи у мрак првог реда/ на дамасту бељем од снега, // радознао шта све та мрља / у сувом стању узгред значи, / уместо даље да чаврља / за столом, опседнут, превлачи // јагодицом великог прста / по њој, жмирећи, док не смести / у њен обрис рој разних врста / мрља наврлих из подсвести // и не поверује у датом / тренутку да у ресторану / нов као космички анатом, // проучава, као на длану, // тамни зев рупе која зјапи / за звездаријом, где је вољом / случаја настала од капи / пале при гатању са шољом, / ко зна када, и која гута / хладни оброк, еон по еон, / а њега пушта још да лута / рубом њене усмине, где он, // отискујући се у доба / мркла чак и за митографа, / склапа очи, као да проба / мешавину најбољих кафа!” (Радовић 1994: 83-84). 
значи да се параболична основа песме изразитије развија у смеру предочавања интроспекције и саморазумевања као недовршивих интерпретативних процеса, тесно условљених унутрашњим (не)свесним „лавиринтима” самог тумача. Уместо поринутости у микрокосмос, параболична путања песме заправо сугерише специфичну визију макрокосмоса, чији саставни део је субјект проучавања „анатомије” универзума, прожет искуством сусрета са непрозирним космичким тајнама.

Песма стога поседује посебну космогонијско-метафизичку димензију, будући да се сугерише настанак самог универзума, наизглед без ослањања на религијску представу о Створитељу. ${ }^{4}$ Ипак, претпоставља се одређена природа самог почетка универзума - он настаје „вољом случаја” - при чему је тај настанак, метафорично казано, реализован при „гатању са шољом”, у време које чак ни „космички анатом”, наизглед рационални субјект перцепције свемира, онај ко се бави његовом анатомијом/структуром/поретком, не може прецизно да одреди (,ко зна када”).

Испоставља се да је у Радовићевој лирској визији почетка универзума уведено низ метафоричних назнака покретача тог почетка - тј. самог случаја - али на начин који деперсонализованом поводу дају персонализоване обрисе (воља, гатање). ${ }^{5}$ Уочавамо да само поверење у те метафоре при опису настанка мрље/универзума, може представљати или одраз становишта похрањених у дистанцираном лирском Над-Ја, или траг језика и перпективе самог лирског јунака/,анатома”, провизорног фокализатора. У оба случаја персонификација пра-почетка још увек чува реторику метафизичког и/или религијског поимање света; отуд је у песми на делу специфичан сусрет воље лирског јунака/,анатома” за интерпретацијом мрље/универзума и одјека метафизичког/религијског наслеђа. Јер, самој „вољи случаја” претходи извесно „гатање” инстанце која је постојала пре универзума, али која није са конкретизованим циљем створила свемир, већ је и сама морала посегнути за „гатањем”, за својеврсним опробавањем среће и „воље случаја”. У свему томе је видљив одјек идеје да постоји сила која је, у космогонијско-метафизичком поретку Радовићеве песме, надређена божанству које „гата” и нема потпуно контролу над стварањем свемира. ${ }^{6}$

\footnotetext{
${ }^{4}$,Тамни зев рупе која зјапи / за звездаријом, где је вољом / случаја настала од капи / пале при гатању са шољом, / ко зна када" (Радовић 1994: 83).

5 Да би се јасније указале семантичке опције које из тога произлазе, неопходно је скренути пажњу и на то да у песми изостаје лирско Ја. Другим речима, уколико приметимо да је изостављен читав низ фактора који би нам помогли да препознамо лирски субјект (попут исказивања у првом лицу и деиктичких одредница које би такву инстанцу профилисале), и уколико се узме у обзир да смислу песме не би значајно допринела опција по којој исказна инстанца о себи говори у другом лицу (рекли бисмо и да такав поступак у овом случају није ни естетски ефектан), онда је најизвесније да је у песми реализован случај лирског Над-Ја, повученог из поља повишено субјективизованог говора и сведеног на посматрачко-дескриптивну функцију (Ужаревић 1987: 1177-1187). Таква инстанца, ипак, на самом крају песме продукује исказ са екскламацијом, што даје за право, уколико се провизорно ослонимо на потенцијале наратолошког тумачења песничких текстова (в. Хин, Шенерт 2005: 1-13), да препознамо афицирање лирско Над-Ја стањем/осећањем уведеног лирског јунака, „господина” који тумачи мрљу.

${ }^{6}$ Не би требало занемарити још једну компоненту параболичне слике - мрља је на дамасту „бељем од снега”, те тако наглашена боја може симболички да упућује на онтолошки квалитет
} 
Та надређена сила у овом случају није нпр. ананке, будући да је реч о модернијој интерпретацији пра-почетка: увођењем случаја као круцијалног мотива Радовићева песма делимично евоцира немогућност мишљења саме природе случаја (отуд случај мора да буде персонификован и да има вољу, тј. мора му се придати антропоморфна нијанса да би се његова непојамна природа, ситуирана у пра-почетку, могла језички симболизовати). Конфигурацијом лирског јунака евоцирано је заправо ограничење његове интерпретације мрље/универзума и делимично прихватање идеје да „више не стојимо иза варијанте начела довољног разлога, према којој постоји нужан разлог зашто је све онако како јест, а не другачије, већ иза апсолутне истине начела безразлога. Нема разлога да ишта буде или да остане онако како јест, све мора без разлога моћи не бити и/или моћи бити другачије него што јест" (Мејасу 2016: 90). Другим речима, самом језику лирског јунака (уколико га прихватимо за провизорног фокализатора), или, с друге стране, перспективи лирског Над-Ја, недостаје одређена симболичка моћ која би уобличила наслућено порекло универзума по начелу безразлога. ${ }^{7}$

Везани стих хуморно-ироничних рима (открићем-пићем, вољомшољом, митографа-кафа) и контекстуализација лирске ситуације амбијентом ресторана - скопчани са мотивима који недвосмислено упућују на космогонијско-метафизички обзор - као последицу имају то да Радовићеву песму истовремено можемо читати и као иронизацију филозофског мишљења „великих тема", али и као њихову модернистичко-скептичну реафирмацију. Типично иронично осциловање између два значења овде је подржано доследним паралелизмом мотивских нити (настанак мрље/настанак свемира), тј. мотиви из тривијалне свакодневице нису само у служби поменутог модернистичког поступка „снижавања” уведене „велике теме”, већ и ради поступног откривања посебног својства феномена који је у фокусу - мишљења крајњих питања. У „Студији у тамном” се заправо открива задовољство у том процесу мишљења и интерпретације, ужитак који читавој лирској ситуацији даје ауру особене „веселе озбиљности”.

контекста у којем се, вољом случаја, објављује мрља/свемир. Као да дискретно остаје могућност да, „иза" снаге случаја и божанства које гата, постоји онтолошка подлога која уведеном атрибуцијом буди позитивне конотације (симболика белог), истовремено се сама указујући као резултат неког рада/ткања, као артефакт (дамаст). Чини се да су, ипак, у значењима Радовићеве песме, остављене и тихе семантичке опције које подразумевају Творца (дамаста).

${ }^{7}$ Интерпретатор мрље/универзума је специфичан и по ужитку при тумачењу, његов повратак „у доба / мркла чак и за митографа” се, препознатљивим модернистичко-иронијским поступком „снижавања” патоса „великих тема”, овде потпомогнутим важном улогом риме (митографа-кафа), пореди са наизглед тривијалним задовољством испијања кафе („Склапа очи, као да проба / мешавину најбољих кафа!” (Радовић 1994: 84).То немисливо доба пре мита је, у параболичној слици, дато као пра-време када „тамни зев рупе (...) зјапи / за звездаријом” (Радовић 1994: 83); управо покушај поимања тог понорног момента, тог тамног зева, прожет је еросом (,Лута / рубом њене усмине” (Радовић 1994: 84). У песми се заправо међусобно прожимају модерни осећај понора, лишен метафизичког избављења, и још од Платона важна повезаност мудрости и ероса (Платон 1979: 73-74). Сам лирски јунак стога провизорно поседује хабитус филозофа, покренутог радозналошћу која се, из модерне перспективе, може препознати као „понорно чуђење” (Финк 1984: 12; истакао Г. К.), а која је у „Студији у тамном” неодвојива од ужитка/ероса. 
Иронија је евидентна и у песми „Рas de trois”, 8 у којој специфични вид балетске игре (у троје), назначен у наслову, заправо описује сцену у којој двојица болничара (,двојица, бело одевена”) одводе жену „у црном” („,одвлаче / до белих кола”), будући да јој је вероватно „ум помрачен”. Краткотрајно је и у овој песми уважена перспектива лирског јунака, односно јунакиње (,да је напросто вознесена"), с тим што су религијско-метафизичке конотације овде дате нешто стишаније него у „Студији у тамном”. Ипак, и у мери у којој постоји, религијско-метафизички аспект зависи од угла тумачења тј. као и у „Студији у тамном”, оно што је перципирано (у претходној песми мрља, овде одвођење лирске јунакиње од људи у белом) - своје значење дугује одређеној перспективи, и њоме је тесно условљено. Лирска јунакиња као провизорни фокализатор условљава ироничне конотације, потпомогнуте управо специфичном римом, односно смисаоним струјањима између римованих речи и стихова: она је „вознесена”, јер је одводе „двојица, бело одевена”, болничари који могу бити анђели у очима пацијенткиње.

Када у „Pas de trois” тачка гледишта очигледније припада дистанцираном лирском Над-Ја, не и лирској јунакињи којој је, претпоставља се, „ум помрачен”, онда лирска ситуација евидентније бива осветљена иронијом која се удаљава од религијско-метафизичког „поља” и тесно зависи од поређења описане трауматичне ситуације са балетом, тј. трауматичан тренутак дисциплиновања „с ума сишавше” не еманира само тегобне асоцијације, већ буди мисао и на елегантну балетску игру. Друго „лице” иронијског обрта је у следећем: називањем помрачења ума балетском игром, заправо се еманира значење по којем нема никакве лепоте у понору губитка разума. Природа трауме се сугерише ироничним приписивањем лепоте тамо где она изостаје.

Не само у претходним песмама, већ и у оним лирским остварењима, видећемо у наставку, која доводе у први план чин песничког стваралаштва, Радовић свет види као поље интерпретације, не чинећи привилегованом ни једну позицију која би уписала једнозначан смисао у свет и егзистенцију. Издвојене Радовићеве песме посредно тематизују саму могућност полиперспективизма, евоцирајући тиме поглед на свет дискретно произашао из ничеанског наслеђа. Употреба ироније је отуд тесно скопчана са увођењем таквог светоназора, јер је осциловање иронијских значења у Радовићевим песмама сигнал да се описане лирске ситуације не могу разумевати погледом из само једне инстанце. Везани стих и риме омогућавају да таква иронија „оживи” у тексту, будући да поменутим песничким средствима долази до продуковања специфичног контекста на који је сам песник рачунао, помињући то у својим аутопоетичким текстовима: рима, наиме, може да подсети „на већ остварене песничке идеје; а наша упућеност у те идеје, мимо самих речи, пружа утисак већ прочитаног. Неки иронијски и пародијски обрти се темеље управо на

\footnotetext{
8 „Возила су заустављена / да улицом за посматраче / пукне брисани простор, сцена / на коју ће да закораче // двојица, бело одевена, / што подсећају на плесаче / или на куваре, и жена / у црном, ситна, која плаче // док јој један грли рамена / а други струк, стегав јаче / кад им се опре, осовљена / на ноге, вешто је одвлаче // до белих кола која с њена / два чувара у белом значе / да је напросто вознесена, / ако јој није ум помрачен” (Радовић 1994: 75).
} 
томе” (Радовић 2001: 77). ${ }^{9}$ Такав контекстуални притисак, неопходан да би се иронија појавила (в. Стојановић 1984), може код рецепијента побудити мисао да је пред текстом већ познатих општих места и тривијалних преокупација, што се, у случају Радовићевих песама везаног стиха, испоставља тек као једна „страна” ироније.

Ни Сламнигове песме метафизичких интенција нису лишене ироније која може да заинтригира тумаче. ${ }^{10}$ Довољно је обратити пажњу на прве стихове песме „Ако ли је нешто нешто”, ${ }^{11}$ на почетку збирке Дронта: у њима се у први план доводе метафизичка питања, те се стихови могу разумети као алузија на креационистичку идеју о „Првом покретачу”, али и као далека парафраза Хајдегеровог питања на почетку Увода у метафизику. ${ }^{12}$ Осим тога, у критици је већ показано да поменуто Сламнигово лирско остварење представља агностичку реплику на Гундулићеву песму „Од Величанстава Божијег”, на апотеозу хришћанске визије настанка света (Фалишевац 2007: 8182). Иронијско-хуморним отклоном од таквог прототекстуалног полазишта заправо се успоставља не само дијалог хришћанског етоса и скептицизма, већ и барокне поетике и модерног поимања (интер)текстуалности. Употреба сестине и осмерачког стиха чини се да није уведена ради превредновања или пак деструирања традицијских облика лирског изражавања, већ управо са циљем манифестације модерних поетичких могућности, тј. реализације модерне лирске субјективности у оквирима формално-изражајног устројства специфичног за барокну дубровачку поезију. До које мере је персона у поменутој песми заправо регулатив кореспонденције два поетичка и епохална хоризонта, показатељ је курзивно истицање цитираних Гундулићевих стихова, чиме се разоткрива прототекстуално полазиште и нешто виљивијим чини имплицирани полемички приступ. ${ }^{13}$

${ }^{9}$ На цитиране Радовићеве увиде већ је скретана пажња као на важне сентенце које могу тумачима да приближе песникове песме везаног стиха у зрелој и познијој фази стваралаштва (Јовић 2018: 60-61).

${ }^{10}$ Поједини интерпретатори одређена Сламнигова остварења неоправдано препознају као политички ангажована, иако неретко нема превише основа за то. Пример је интерпретација уводне песме збирке Дронта, „Ако ли је нешто нешто”, чији се стихови („Мисао без протумисли / без промјене, без престанка / гдје смо сами себе стисли, / нема вишка, нема мањка; / $u$ y сили свој огњени / и љубовник и љубљени", Сламниг 1990: 279) препознају као критички опис друштвено-политичког живота у СФРЈ (в. Буљац 2011: 131).

${ }^{11}$ „Ако ли је нешто нешто / и онда кад другог нема”, (Сламниг 1990: 279).

12 „Зашто је уопште оно што бива, а не чак ништа?” (Хајдегер 1976: 19).

13 Такво типографско истицање цитата у односу на остатак текста није чест поступак у Сламниговој лирици; то, ипак, не значи да се предложак с којим се успоставља интертекстуална веза увек прикрива - каткад се већ у наслову реферира на поједине ауторе или остварења, као што је случај са песмом „Слага Гундуо о прошастју”. У њој се лирски субјект конципира на сродан начин као у песми „Ако ли је нешто нешто”- он подразумева персону специфичну по универзализацији становишта, по изношењу сопственог искуства као важећег за неименовано Ми (,на хипу се бријеме врти, / то нас спашава од смрти”, Сламниг 1990: 310), све то уз модерно преиначење барокне представе пролазности изнете у Гундулићевим Сузама сина разметнога. То прате и ритмичко-формални оквир преузет од дубровачког песника и фразеологија особена за простор Дубровника. На Гундулућеве стихове („Што је било, прошло је веће”) лирски субјект Сламниговог остварења пружа представу времена која подразумева „вечно враћање истог” (,,а дојдућег века слика / само овог је прилика”, Сламниг 1990: 310). Детаљна анализа Сламниговог „одговора” на Гундулићеву поему у: Фалишевац 2007: 82-83. 
Већ у овим примерима видљиво је да лирско Ја губи на плану психологизације, и постаје дискурзивни резултат компарирања етоса и песничких пракси који су вековима удаљени. Сама песма постаје плод (интер)текстуалне комбинаторике, пролиферације илустративне цитатности, дезавуисања представе о метафизичким дометима песничког стваралаштва; она је одраз песничке самосвести о конвенционалности употребљаваних поступака и, у појединим случајевима, резултат осциловања између пастиша и пародије. Песма постаје, дакле, „простор” козеријског укидања хијерархија поетичко-обликотворних принципа и повлашћености било којег изражајног идиома. Све то је, свакако, давало повода да се Сламнигова поетика препозна делимично као постмодернистичка.

Песма „Релативно наопако” из истоимене збирке пример је како се, задржавањем иронијско-хуморног приступа, остаје у пољу метафизичких питања, али без видљивог оживљавања интертекстуалних веза. Пре је реч о другом, подједнако честом поступку у Сламниговој поезији - о укрштању и међусобно осветљавању метафизичко-егзистенцијалних тема и љубавних мотива, све то из иронијско-хуморне перспективе лирског Ја. Отуд се, у поменутој песми, на идеју о могућој љубавној превари - артикулисану иронијским исказивањем које не даје коначан одговор на то да ли ће до преваре доћи ${ }^{14}$ - надовезују питања о крајњој судбини свемира. ${ }^{15}$ Уводећи однос Ајнштајна и Милеве Марић као копчу између љубавног и макрокосмичког плана, лирско Ја остварује паралелизам при којем се одлике те две уведене равни међусобно пресликавају. Отуд је изокретање теорије о ширењу свемира једним делом сугестија да у самој љубави има одређеног враћања на почетак, „у једно једино осмишљење / које само из себе никну”. „Осмишљење” које ниче само из себе - чин који се, парадоксално, испоставља као самодовољан иако сама реч („осмишљење”) говори да је реч о резултату деловања/мишљења одређеног субјекта - заправо открива да у љубави има нечег непојмљивог, као и у почетку универзума који сам из себе настаје. Говорећи, дакле, о свемиру који, из угла лирског Ја, пулсира у ширењу и поновном повратку у тачку настанка, без интервенције Првог покретача, истовремено се сведочи о томе да је љубав, бадјуовски казано, Догађај који не зависи од воља субјеката који у њему учествују. ${ }^{16}$

14 „Да ли да преварим своју драгу? / Није ми баш воља, / Све су добре, дапаче, одличне, / Ал ни једна није боља" (Сламниг 1990: 433).

15 „Криво је причао умишљени Einstein, / Није разумио Милеву / Марић (...) // Свемир не експандира / него се стишће у пикњу, / у једно једино осмишљење / које само из себе никну" (Сламниг 1990: 433).

${ }^{16}$ Хуморна интонација - подржана употребом риме на начин који је већ Борислав Радовић одредио као погодан за презентовање наизглед тривијалних тема и идеја - отежава појаву патоса при говору о љубави, истовремено чинећи да тематизовање судбине универзума не добије псеудофилозофичну димензију; с друге стране, хуморна употреба везаног стиха каквом Сламниг прибегава обезбеђује да се ненаметљиво „кријумчаре” идеје о свету без Бога. Све то је добрим делом условљено персоном која преузима маску наивности - поступком који се неретко може срести у Сламниговој лирици. Испод такве „образине” указује се иронични лирски субјект који заправо одбија да буде међу онима који са „патосом озбиљности (...) површно и задовољно” (Ниче 1989: 111) приступају „крајњим питањима”. 


\section{О певању које „далеко дуже значи”}

И Радовић и Сламниг, извесно је, посежу за темама које упућују на прекорачење емпиријске егзистенције, посматрајући их, начелно казано, кроз једну нихилистичку оптику која омогућава да се „студије у тамном” код српског песника укажу у кључу специфичног полиперспективизма, а код хрватског и у хуморном светлу, преломљене каткад кроз ироничну рефлексију о љубави. Иронијски хабитус исказивања у везаном стиху је заједнички именитељ поступака за којима ова два песника посежу.

Када су посреди песме које доводе у први план само стваралаштво, вреди најпре скренути пажњу на Радовићеву „Митску причу” која се бави формирањем митских наратива, али која свакако посредно евоцира саме почетке песничког говора, односно „оно доба када су ткачи / митова вукли митске нити" (Радовић 1994: 114). Певање у временима митског мишљења неизоставно подразумева слављење хероја. ${ }^{17}$ Постојање „митског рубља” у миту/ причи/песми условљено је конкретним разлогом (,прича није дубља / али далеко дуже значи”, Радовић 1994: 115).

„Прљаво митско рубље” неизоставно подразумева да сви они, начелно казано, не нужно херојски аспекти формирања ликова, могу да буду приписани управо носиоцима митских наратива. Такве компоненте лика хероја имплицирају две последице: најпре, прича тиме не постаје „дубља”, али, с друге стране, „далеко дуже значи”. „Дубља” прича би свакако подразумевала далекосежна значења која предочавају одређене универзално релевантне аспекте егзистенције; међутим, стиче се утисак да то није довољно да прича „путује” кроз епохе. Траг тривијалности и уношење антихеројских својстава у изградњу херојског лика постаје гарант да ће се прича преносити из генерације у генерацију.

Шта се заправо сугерише Радовићевом песмом? Најпре, универзална и кроз епохе преносива значења не подразумевају нужно идеализацију хероја, чак се сугерише изразитија пријемчивост приче уколико херој поседује особине које припадају нехеројском свету. Универзални аспект митских прича заправо бива употпуњен када се деидеализује антрополошка слика инкорпорирана у причи - прича дуже траје јер сугестивније говори о самој људској природи, о њеним светлим и тамним странама. Отуд рима рубља-дубља одражава посебну песничку инвенцију. „Прљаво митско рубље” заправо „игра” двоструку улогу: његовим приближавањем означитељу „дубља” оспорава се одрживост саме „дубине” приче, али се она истовремено управо тиме чини слојевитијом и ближом искуству оних који приче посредују. Означитељ „рубље” одузима патос „дубини” приче, „помажући” јој заправо да се укаже у новом светлу. Радовић у ствари нуди занимљиву визију мита, посредно и

17 „Посебно су хвалили претке, / уносећи у митске свеске / подвиге опасне и ретке”, (Радовић 1994: 114), уз специфичан додатак („Унели би (...) нешто прљавог митског рубља”, (Радовић 1994: 114). 
књижевног стварања - тек обједињавањем „високог” и „ниског” регистра у репрезентацији јунака остварује се прича која надилази оквире своје епохе.

Друга важна импликација Радовићевог поимања мита може се указати уколико међу „прљавим митским рубљем” препознамо и могућност уношења опсцених детаља у причу. Такви детаљи се не придружују причи „без небеске подршке ни без родољубља", чиме се у песми дискретно проговара из модерније перспективе сенчене свешћу о политичко-идеолошким аспектима наратива са „прљавим митским рубљем”. Има се заправо на уму да је „полигон 'универзалних истина' прожет сексуалношћу која је протурјечно уплетена у низове означитеља као њихова унутарња-извањскост, иманентна немоћ да зауставе свој плес. Дакле, како би симболичке процедуре националне традиције и владајуће идеологије биле учинковите, кроз њихове форме мора проћи необуздана 'опсцена' материја” (Вуковић 2005: 119). „Полигон универзалних истина" свакако обухвата и митске приче, те опсценост у њиховом ткиву није нужно знак тривијализације, већ може подразумевати иманентно својство оног аспекта наратива који се из модерније перспективе може именовати као политичко-идеолошки.

Својеврсна песничка допуна сугерисаних идеја дата је у песми „Headline News", у којој наратив о Гилгамешу бива предочен сензационалистички, као вести са насловних страна савремених медија. ${ }^{18}$ У таквој параболично-иронијској реинтерпретацији древног епа његов садржај „слободни свет (...) с изузетком / неких редова, посла до нас" (Радовић 1994: 117). Иронија у наведеним редовима је вишеструка: осим што се сугерише да би опсцено-сензационалистички симулакрум савремених медија успео да и далекосежно значајан књижевни наратав преточи у тривијалну вест, скреће се пажња и на то да сам књижевни наратив представља фикционализацију, одређено (пре)обликовање „грађе” из искуства/стварности, уз присуство „прљавог митског рубља”. Одсуство „неких редова” у коначном „резултату”, сходно успостављеној иронији, доноси неколико потенцијалних значења: може бити речи о неопходној редукцији наратива при књижевном уобличењу, али и о чињеници да је знање о књижевностима древних цивилизација засновано на оним књижевним артефактима преживелим кроз време, и самим неретко фрагментарним. Уз то, уколико назначено преношење наратива о Гилгамешу схватимо као посредну сугестију природе медија, губитак „неких редова” упућује на могућност изостанка важних детаља посредоване вести, можда управо оних који би, сачувани, рецепијентима омогућили да саму вест разумеју и доживе на начин другачији од примања њене непотпуне верзије. Изостанак „неких редова” свакако побуђује полиперспективизам (при тумачењу саме вести), сугерисан још у „Студији у тамном”. ${ }^{19}$

18 „Кад Гилгамеша удари мучки / Хумбаба ногом у мошнице, / тргови урски, то јест уручки, / брујаху налик на кошнице // (...) // Кад се Гилгамеш секире лати, / Хумбабин састав да испроба, / уредништво је могло да прати / како освиће ново доба" (Радовић 1994: 117).

${ }^{19}$ Иронијски је третирано и трубадурско стваралаштво, при чему сама иронија одузима патос тематизованом феномену, истовремено не поричући потпуно његову релеванцију. У песми „Провансалске сличице” се отуд формира паралелизам између витешког живота и трубадурског песничког чина („Нешто је нагонило праве / витезове да каткад проспу / више мастила него 
Сламниг је, чини се, склонији да својој иронији прида и друштвено-критичку оштрицу. У његовој краткој песми „Литература” сам књижевни позив је контекстуализован друштвеним околностима. ${ }^{20}$ Формирајући песничко Ја које поседује хабитус емпиријског аутора и (још једном) подразумева маску наивности, Сламниг у први план наизглед ставља проблем стваралачке несигурности и недоумица: када би (лирски субјект) мање био изложен погледима читалачке публике, слободније би приступао самом стваралаштву. Наличје иронијских исказа је јасно - алудира се на идеолошки осетљиву читалачку перспективу која у песничким текстовима може препознати идеолошки неподобна значења. На сродном трагу, у песми „Књижевност и живот", тема цензуре се козеријски трансформише у алузију на међунационалну напетост. ${ }^{21}$

Од непосредније иронијске тематизације друштвеног статуса песничког стваралаштва за Сламнигову поетику је значајније имплицитно поимање текстуалности. Већ је напоменуто да се неретко његова поетика разумева као гранична према постмодернизму, што се посебно може видети у песми „Некад сам био миш и све", у којој се превреднује у основи модернистичко поимање текстуалности, самим тим и песничког стваралаштва. Наиме, у песми се малодушно осећање лирског $\mathrm{Ja}^{22}$ пореди са судбином истребљене врсте птице додо, дронте, уз фусноту која у целовитости представља цитат из орнитолошког списа с краја XIX века. Појашњење претходног мотива лирског текста другим текстом, дискурсом који лако напушта научну строгост, производи комичне ефекте и самим ситуирањем у фусноти деструира аутономију лирике као жанра. ${ }^{23}$ Реч је, дакле, о облику интертекстуалне игре који изи-

плаве / крви за изабрану госпу. // Зими би, док им штитоноше / и лимари глачају тешке / атрибуте, знали да троше / кишни дан на ред-два без грешке”, Радовић 1994: 71). У наставку песма заправо осцилује између дискретне иронизације метафизичких претензија песништва („Уз сјај свећа / и топао камин би стално / продубљивали до пролећа / продор у ирационално”, Радовић 1994: 71) и иронијски третиране напетости између херојско-маскулиног принципа и повишене песничке сензибилности (,Док би орибани рукави / прикривали да нека лавља / срца имају мастиљави/ траг и на свили зарукавља”, Радовић 1994: 72). „Провансалске сличице” је још једна из низа Радовићевих песама у којима је иронија средство откривања наличја одређене појаве, с тим што то нужно не значи и снажнији критички однос према самој појави која је тематизована. Другим речима, Радовићева иронија омогућава да се ни један од уведених мотива - ирационалне тенденције у песништву, херојско-маскулин принцип и песнички позив - не поима као самодовољан и саморазумљив; при томе се, иза таквог иронијског отклона, не крије и идеја о неодрживости сваког од тематизованих феномена.

${ }_{20}$ „Неки дан кад смо били код Новака / разговарали смо и о литератури / о Мирославу и о Славу / о Пери и о Јури // па како нитко нас не чита / и да све губи смисао. / О да ме нитко бар не чита / слободније бих писао” (Сламниг 1990: 457).

${ }^{21}$ „Књижевност није happening / него је низање ријечи / немој га убити зато што пише / него га пристојно спријечи. // Живот је сигурно happening / и Адамов и Евин / и Cintijin и Percivalov / и Стјепанов и Стевин”, (Сламниг 1990: 444).

22 „Некад сам био ниш и све, / а сад сам опет ниш и не, // (...) // и бљутав сам ко дронта (додо)", (Сламниг 1990: 301).

${ }^{23}$ Један део цитата из студије Стјепана Гјурашина, објављене 1899-е године, који представља лични коментар на судбину птице додо и који придодаје аутсајдерску ауру лирском Ја, гласи: „Та ругоба је била уз то врло тупа, те су је људи могли по вољи штаповима убијати и тако напокон посве изтриебити. Месо јој није ваљало и изим можда стручњака не ће ваљда нитко пожалити, што је таквог ругла из птичјег света нестало” (Сламниг 1990: 301). 
скује да се значење песме тражи у кореспонденцији самог лирског текста са успостављеним паралитерарним контекстом, „заслужним” за депатетизацију теме егзистенцијалистичке провенијенције.

У наведеном случају лирски субјект „носи” персону песника/аутора бивајући обележен и дискретном идентификацијом, ${ }^{24}$ поистовећењем са ишчезлом птицом услед чега лирско Ја провизорно добија и зооморфну персону. На крају песме, у завршном дистиху, ${ }^{25}$ кријумчари се, осим гласа лирског Ја, и глас инстанце лишене емпатије за ишчезлу врсту. Ако не узмемо у обзир наведено вишегласје у последњим стиховима, ако, дакле, останемо при ставу да је реч о континуитету исказивања једне инстанце, можемо препознати буфонерски однос лирског Ја према репресији и насиљу. С друге стране, неемпатични тонови у исказивању комплементарни су са пратећим, паралитерарним дискурсом фусноте и у улози су метафоричног посредовања гласова оних који врше насиље над било којом аутсајдерском фигуром. На имплицитном поетичком плану, такво вишегласје открива да се инстанца лирског Ја формира на интертекстуалним везама, а да је само песничко стваралаштво једним делом резултат интердискурзивне коресподенције.

\section{Закључак: преиспитивања и афирмације у ничеанском „шињелу”}

Извесно је да и Радовић и Сламниг у песмама везаног стиха остварују значења која их приближавају филозофској перспективи у основи ничеанске провенијенције. У њиховим песмама везаног стиха приметна је иронија, с тим што учествовање у светоназору ничеанског предзнака бива реализовано разноврсним манифестацијама ироничног исказивања. Радовић неретко у песмама везаног стиха од лирских јунака дискретно чини провизорне фокализаторе, те уведене лирске ситуације бивају ненаглашено сагледане из више углова. Тиме се посредно упућује на неизбежност полиперспективизма, на немогућност метафизичке, односно идеолошке легитимације једне интерпретативне перспективе, све то на трагу става да „постоји само перспективно гледање, постоји само перспективно 'сазнавање”, јер се управо „различитост перспектива и страсних тумачења уме искористити за сазнање" (Ниче 1986: 120-121).

Наведене Ничеове идеје које су учествовале у генерисању многих филозофских токова XX века - између осталих и оних деконструкцијског профила - представљају важан контекст за разумевање Радовићевих песама попут „Студије у тамном”, „Pas de trois” и „Headline News”, с тим што таква контекстуализација не имплицира да српски песник строго кореспондира са деконструкцијским мишљењем. Наведене песме су управо пример високо-

\footnotetext{
${ }^{24}$ „И бљутав сам ко дронта (додо) / ко кад сам Ile de Franceom одо / и чеко штап за сваким углом", (Сламниг 1990: 301).

${ }^{25}$ „Што лети слабо, а бјежи лошо. / О баш је добро што је ошо”, (Сламниг 1990: 301).
} 
модернистичког прилажења граници са постмодернизмом, уз недвосмислено задржавање у модернистичком пољу: иронија посредована везаним стихом - односно римама које приближавају тривијалне и наизглед песнички повлашћене мотиве - демистификује „велике теме” али их истовремено и изнова афирмише, управо захваљујући могућности њиховог сагледавања из више углова.

Када у песмама у везаном стиху тематизује митски говор или само певање, Радовић иронијским исказивањем чини видљивим наличја општих места која су повезана са једнодимензионалном визијом мита или представама о трубадурском песништву. Сламниг иронију употребљава не би ли истовремено проговорио и о књижевном стваралаштву и о идеолошко-друштвеном контексту који на само стваралаштво може репресивно да делује. Нешто суптилније, иронију уводи када настоји да истовремено иронијским копчама међусобно приближи метафизичке и љубавне мотиве, депатетизујући их уз истовремено враћање њихове релеванције, сродно Радовићевим семантичким резултатима. Као и српски песник, и Сламниг таквим песничким остварењима остаје у пољу модернизма.

Искорак ка постмодернистичким праксама постоји у случајевима када Сламнигова поетика - повремено специфична по иронично-критичком односу према друштвено-политичким питањима и релацији књижевност-друштво - постаје изразитије текстоцентрична, када у игривој коресподенцији пастиша, пародијских импулса и интертекстуалних веза имплицира дијалоге различитих модуса песничког изражавања или различитих песничких епоха/поетика. Везани стих у том случају може бити функционална копча за додир барокне и (пост)модерне поетике („Ако ли је нешто нешто”, „Слага Гундуо о прошастју”), односно привидно тривијалног песничког говора и паралитерарног дискурса („Некад сам био миш и све”), чије увођење у последњем случају евоцира идеологизовано-деструктивну инстанцу. Хрватски аутор, као и Радовић, начелно формира поетику у оквиру мишљења добрим делом одређеног ничеанским идејама, што је посебно уочљиво у Сламниговим песмама постмодерног хабитуса, сходно ставовима по којима управо постмодерна мисао, у свом превреднујућем замаху, много тога дугује ничеанској перспективи. С тим што, као у Радовићевим песмама, сенку „снижавања” тзв. „великих тема”, чак и када постоје трагови пародије, прати специфичан егзистенцијалистички призвук и одржање релеванције мишљења о „крајњим питањима". Оба аутора заправо проналазе меру да иронично, у песмама везаног стиха, провизорно обитавају, свако у складу са својом поетиком, у близини границе између модернизма и постмодернизма. 


\title{
ЛИТЕРАТУРА
}

Буљац 2011: M. Buljac, Pjesništvo Ivana Slamniga - opis i mikrostrukture, u: K. Bagić (ur.), Ivan Slamnig: ehnti tschatschine Roge!, Zagreb: AGM, 121-135. Вуковић 2005: T. Vuković, Svi kvorumaši znaju da nisu kvorumaši, Zagreb: Disput. Јовић 2003: B. Jović, Uloga rime u poeziji Borislava Radovića, u: E. Halilović (ur.), Borislav Radović: pesnik, Novi Pazar: Građanski forum.

Mejacy 2016: Q. Meillassoux, Poslije konačnosti: esej o nužnosti kontingencije, preveo V. Šeput, Zagreb: Multimedijalni institut.

Ниче 1989: Ф. Ниче, Весела наука, превод М. Табаковић, Београд: Графос.

Ниче 1986: Ф. Ниче, Генеалогија морала, превод Б. Зец, Београд: Графос.

Хин, Шенерт 2005: P. Hünn, J. Schönert, Introduction: The Theory and Methodology of the Narratological Analysis of Lyric Poetry, In: P. Hünn, J. Kiefer, The Narratological Analysis of Lyric Poetry, Berlin, New York: Walter de Gruyter, 1-13.

Платон 1986: Platon, Ijon. Gozba. Fedar, prevod M. N. Đurić, Beograd: BIGZ. Радовић 1994: Б. Радовић, Песме, Београд: СКЗ.

Радовић 2001: В. Radović, O pesnicima i poeziji, Banja Luka: Glas srpski.

Сламниг 1990: I. Slamnig, Sabrane pjesme, Zagreb: GZH.

Стојановић 1984: D. Stojanović, Ironija i značenje, Beograd: Zavod za udžbenike i nastavna sredstva.

Ужаревић 1987: J. Užarević, Lirsko Nad-Ja i/ili lirski paradoks, Filozofska istraživanja, 7 / 4, Zagreb, 1177-1187.

Фалишевац 2007: D. Fališevac, Dubrovnik kao izazov hrvatskim liricima 20. stoljeća, Hvar / Dani Hvarskog kazališta, Hvar, 33 / 1, 69-94.

Финк 1984: E. Fink, Osnovni fenomeni ljudskog postojanja, prevod A. Buha, Beograd: Nolit.

Хајдегер 1976: М. Хајдегер, Увод у метафизику, прев. В. Ђаковић, Београд: Вук Караџић.

Goran P. Korunović

\author{
MERRY POETIC “SCIENCE”: COMPARATIVE APPROACH TO THE POEMS \\ IN FORMAL VERSE BY BORISLAV RADOVIĆ AND IVAN SLAMNIG
}

\section{Summary}

The aim of this paper is a comparative analysis of Borislav Radović's and the Croatian poet Ivan Slamnig's formal verse poems. The focus of this analysis will be the usage of ironic method in the process of thematizing the metaphysical motifs and the question of poetic creation. By examining the conjunction of irony and formal verse in dealing with the metaphysical topics and the articulation of the understanding of the poetic act, both authors realize specific metalyrical levels of their poems. Special attention will be paid to the ways of executing irony and the questions of its reception, i. e. the possible readerly recognition of the meanings as being ironic and, simultaneously, devoid of irony. Finally, the importance of the suggested methods will be observed in a wider literary and historical, and poetic context, i. e. as an example of a modernistic treatment of the metaphysical and creational questions in the time of the surge of postmodernist poetics. 